\title{
Interaction of glucagon and pentagastrin on pepsin secretion in healthy subjects*
}

\author{
J CHRISTIANSEN, $\dagger$ J J HOLST, and J MOLIN
}

From the Department of Surgery D, Glostrup Hospital, Institute of Medical Physiology C, University of Copenhagen, and the Department of Clinical Chemistry, Bispebjerg Hospital, Copenhagen, Denmark

SUMmaRY The effect of pentagastrin in step-wise increasing doses of $0 \cdot 02,0 \cdot 2,2 \cdot 0$, and 20 $\mathrm{nmol} / \mathrm{kg} / \mathrm{h}(0 \cdot 01,0 \cdot 1,1 \cdot 0$, and $10.0 \mu \mathrm{g} / \mathrm{kg} / \mathrm{h})$ on pepsin and acid secretion was studied in seven healthy subjects. The study was repeated on another day during infusion of glucagon in a dose of $103 \mathrm{pmol} / \mathrm{kg} / \mathrm{h}(0.36 \mu \mathrm{g} / \mathrm{kg} / \mathrm{h})$ which results in plasma-glucagon concentrations comparable with those seen after a protein-rich meal. Pepsin output was maximal after $0.2 \mathrm{nmol} / \mathrm{kg} / \mathrm{h}(0 \cdot 1 \mu \mathrm{g} / \mathrm{kg} / \mathrm{h})$ of pentagastrin and $20 \mathrm{nmol} / \mathrm{kg} / \mathrm{h}(10 \mu \mathrm{g} / \mathrm{kg} / \mathrm{h})$ resulted in a marked decrease. The dose of pentagastrin required for half-maximal pepsin output was less than $0 \cdot 1 \mathrm{nmol} / \mathrm{kg} / \mathrm{h}(0 \cdot 05 \mu \mathrm{g} / \mathrm{kg} / \mathrm{h})$. When the study was repeated during infusion of glucagon, the dose-response curve was shifted to the right. The highest pepsin output was obtained with $20 \mathrm{nmol} / \mathrm{kg} / \mathrm{h}(10 \mu \mathrm{g} / \mathrm{kg} / \mathrm{h})$ of pentagastrin and $\mathrm{D}_{50}$ increased to well over $1 \mu \mathrm{g} / \mathrm{kg} / \mathrm{h}$. The dose of pentagastrin required for half-maximal acid secretion was about $0.3 \mathrm{nmol} / \mathrm{kg} / \mathrm{h}(0.15 \mu \mathrm{g} / \mathrm{kg} / \mathrm{h})$ indicating that the sensitivity of the chief cells to pentagastrin is more than three times that of the parietal cells.

There is evidence that pancreatic glucagon participates in the physiological inhibition of gastric acid secretion. ${ }^{12}$ Whether glucagon is involved in the physiological control of pepsin secretion also is unknown, as previous studies on glucagon and pepsin secretion have been performed with supraphysiological doses of glucagon. ${ }^{3-5}$

The present study investigates the dose-response relationship of pentagastrin and pepsin secretion and the effect on the dose-response curve of glucagon administered exogenously in a dose resulting in plasma concentrationsa comparable with those seen after a protein-rich meal.

\section{Methods}

\section{SUBJECTS}

Seven healthy volunteers, four men and three women with a median age of 26 years (21-34 years), were studied. Informed consent was obtained in every case.

\footnotetext{
* This study was supported by the Danish Hospital Foundation for Medical Research. Region of Copenhagen, The Faroe Islands and Greenland (Grant no. 78-9).

† Address for correspondence: John Christiansen, Department of Surgery D, Glostrup Hospital, University of Copenhagen, DK-2600 Glostrup, Copenhagen, Denmark.

Received for publication 1 September 1981
}

\section{EXPERIMENTAL PROCEDURE}

Each subject was studied twice on separate days. On the first day a step dose-response study of the effect of pentagastrin on gastric acid and pepsin secretion was performed. After an overnight fast, a Levin tube was positioned under fluoroscopic control and the stomach was emptied. Through a thin polyvinyl tube welded to the Levin tube ${ }^{51} \mathrm{Cr}$-EDTA dissolved in $0.9 \%$ saline was infused with a flow of $30 \mathrm{ml} / \mathrm{h}$ in order to determine recovery. Basal secretion was collected for one hour. Pentagastrin was administered by continuous intravenous infusion in doses of $0 \cdot 02,0 \cdot 2,2 \cdot 0$, and $20 \mathrm{nmol} / \mathrm{kg} / \mathrm{h}(0 \cdot 01,0 \cdot 1,1 \cdot 0$, and $10 \cdot 0 \mu \mathrm{g} / \mathrm{kg} / \mathrm{h}$ ), each dose being administered for one hour. (These doses of pentagastrin were the same as those used in a previous study of pentagastrin glucagon interaction on acid secretion. ${ }^{1}$ ) On the second day the step dose-response study with pentagastrin was repeated but now on a background infusion of glucagon in a dose of $103 \mathrm{pmol} / \mathrm{kg} / \mathrm{h}(0.36$ $\mu \mathrm{g} / \mathrm{kg} / \mathrm{h}$ ). Glucagon Novo was diluted in saline containing, in addition, $1 \%$ human albumin, which prevents adherence of the hormone to glass syringes and plastic tubes. Infusion of $103 \mathrm{pmol} / \mathrm{kg} / \mathrm{h}(0 \cdot 36$ $\mu \mathrm{g} / \mathrm{kg} / \mathrm{h}$ ) with this technique results in the same plasma glucagon concentrations as infusion of 460 $\mathrm{pmol} / \mathrm{kg} / \mathrm{h}(1.6 \mu \mathrm{g} / \mathrm{kg} / \mathrm{h})$ without addition of albumin to the diluent, a dose which in a previous study was 
calculated to be $D_{50}$ for inhibition of pentagastrin stimulated acid secretion in healthy subjects and which gave plasma glucagon concentrations comparable with those seen after a protein-rich meal. ${ }^{1}$ The glucagon infusion was started one hour before the infusion of pentagastrin. Through a cubital vein blood samples for analysis of pancreatic glucagon and glucose were taken every 15 minutes. All infusions were administered with a flow of 30 $\mathrm{ml} / \mathrm{h}$. On the first day isotonic saline containing $1 \%$ albumin was administered intravenously as a control infusion.

\section{LABORATORY ANALYSIS}

The volume of gastric secretion was measured for each 15 minute period and the concentration of $\mathrm{H}^{+}$ was determined by titration to $\mathrm{pH} 7.0$ with an autotitrator (Radiometer, Copenhagen, Denmark). ${ }^{51} \mathrm{Cr}$-EDTA was determined in a well counter and the volume of secretion and the output of $\mathrm{H}^{+}$and pepsin corrected according to the actual recovery. As a control of duodenogastric reflux, the osmolarity of each sample was determined by freezing point reduction.

Pepsin in gastric juice was measured using a modification of the Hunt method for estimating peptic activity in gastric juice. ${ }^{67}$ The analysis determines the total peptic activity of the gastric juice at $\mathrm{pH} 1.9$ with freeze dried human citrated plasma as protein substrate. The standard used was crystalline pepsin (Mann Research Lab.).

The plasma concentration of pancreatic glucagon was determined radioimmunochemically. The glucagon antiserum (4305) is highly specific for pancreatic glucagon and cross-reacts less than $0.1 \%$ with high concentrations of enteroglucagon, and does not cross-react with secretin, VIP, GIP, cholecystokinin, or gastrin. Detection limit of the assay is $5 \mathrm{pmol} / \mathrm{l}(17 \mathrm{pg} / \mathrm{ml})$, the within-assay coefficient of variation is $16 \%$, and measurements of glucagon in dilutions of plasma with added glucagon in different concentrations yielded results which deviated less than $10 \%$ from the expected results. ${ }^{8}$

Blood glucose was determined by the hexokinase method. ${ }^{9}$ Pepsin and acid output during the last 30 minutes of each hour were plotted against dose of pentagastrin after subtraction of basal secretion that is, dose 0 corresponds to response 0 . The approximate dose of pentagastrin required for halfmaximal pepsin and acid secretion $\left(D_{50}\right)$ was estimated from the dose-response curves. The $D_{50}$ for pentagastrin stimulation of acid secretion was also calculated by linear transformation of the Michaelis-Menten equation according to DowdRiggs $^{10}$ using the formula: $V=V_{\text {max }}-D_{50}$ (V/D), where $\mathrm{V}$ is the response, $\mathrm{V}_{\max }$ is the calculated maximal parietal cell response, and $\mathrm{D}$ is the administered dose of pentagastrin. These calculations were performed on the individual data after subtraction of basal values by computerised estimation of the regression line according to the method of least squares. For the statistical analysis Student's $t$ test for paired observations was used. Values are given as mean \pm SEM.

\section{Results}

Pepsin and acid output are shown in the Table. Pepsin output relative to maximum output during stepwise increasing doses of pentagastrin is shown in Fig. 1 (upper curve). Maximum output $(37 \pm 4$ U/30 $\min$ ) was reached during infusion of $0.1 \mu \mathrm{g} / \mathrm{kg} / \mathrm{h}$ of pentagastrin and was maintained during infusion of $1 \mu \mathrm{g} / \mathrm{kg} / \mathrm{h}$, while increasing the dose to $10 \mu \mathrm{g} / \mathrm{kg} / \mathrm{h}$ resulted in a significant decrease in pepsin output $(p<0.01)$. From the dose-response curve $D_{50}$ for pentagastrin was found to be less than $0.05 \mu \mathrm{g} / \mathrm{kg} / \mathrm{h}$. On a background infusion of glucagon the doseresponse curve was shifted to the right (Fig. 1, lower curve). The highest pepsin output was the same as during infusion of pentagastrin alone $(35 \pm 4 \mathrm{U} / 30$ min, $\mathrm{p}<0 \cdot 10$ ) but was obtained only with the highest dose of pentagastrin $(20 \mathrm{nmol} / \mathrm{kg} / \mathrm{h} ; 10 \mu \mathrm{g} / \mathrm{kg} / \mathrm{h})$, and no dose reversal (inhibition by larger doses) was observed. $\mathrm{D}_{50}$ for pentagastrin during glucagon infusion was found to be well over $2 \mathrm{nmol} / \mathrm{kg} / \mathrm{h}$ (1 $\mu \mathrm{g} / \mathrm{kg} / \mathrm{h})$.

Acid output was significantly reduced during the combined infusion of pentagastrin and glucagon compared with infusion of pentagastrin alone (Fig. 2). Maximum output obtained decreased from $17 \pm 5$ to $8 \pm 2 \mathrm{mmol} / 30 \mathrm{~min}(\mathrm{p}>0.01) . \mathrm{D}_{50}$ for acid secretion was approximately $0.3 \mathrm{nmol} / \mathrm{kg} / \mathrm{h}(015$ $\mu \mathrm{g} / \mathrm{kg} / \mathrm{h}$ ).

Recovery of gastric juice ranged between 81 and 97\% in all experiments. During infusion of pentagastrin and saline the osmolarity of gastric juice was $243 \pm 8 \mathrm{mmol} / \mathrm{l}$ and during infusion of pentagastrin and glucagon $251 \pm 7 \mathrm{mmol} / \mathrm{l}(\mathrm{p}>0 \cdot 10)$.

Table Pepsin and acid output during increasing doses of pentagastrin with and without infusion of glucagon $(0.36$ $\mu g / k g / h)($ mean $(S E M)$ )

\begin{tabular}{|c|c|c|c|c|}
\hline \multirow{2}{*}{$\begin{array}{l}\text { Dose of } \\
\text { pentagastrin } \\
(\mu g / \mathrm{kg} / \mathrm{h})\end{array}$} & \multicolumn{2}{|c|}{$\begin{array}{l}\text { Pepsin output } \\
\text { (meq } \mathrm{H}^{+} / 30 \text { min) }\end{array}$} & \multicolumn{2}{|l|}{$\begin{array}{l}\text { Acid output } \\
\text { (U/30 min) }\end{array}$} \\
\hline & -Glucagon & + Glucagon & -Glucagon & +Glucagon \\
\hline 0.01 & $5 \cdot 1(1 \cdot 8)$ & $3.5(1.3)$ & $15 \cdot 1(1.9)$ & $14 \cdot 2(2 \cdot 0)$ \\
\hline $0 \cdot 1$ & $8 \cdot 2(1.6)$ & $4.2(1.2)$ & $37.1(3.9)$ & $17.4(2.5)$ \\
\hline 1.0 & $16 \cdot 8(2 \cdot 1)$ & $7.9(1.6)$ & $35 \cdot 2(3 \cdot 6)$ & $17 \cdot 8(2 \cdot 1)$ \\
\hline 10.0 & $17.0(5 \cdot 0)$ & $8.2(1.7)$ & $21.0(2 \cdot 8)$ & $35.0(2.9)$ \\
\hline
\end{tabular}




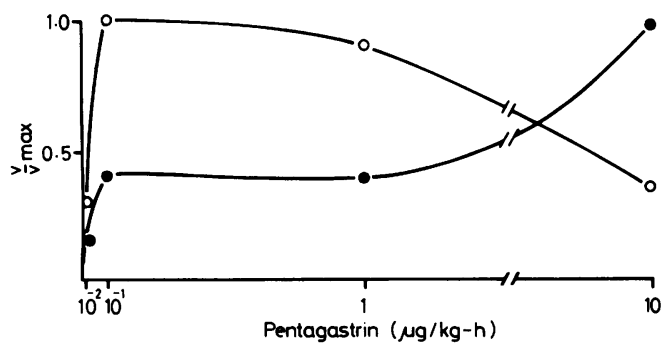

Fig 1 Gastric pepsin output relative to maximum output $\left(V / V_{\max }\right)$ during intravenous administration of increasing doses of pentagastrin $\left(\mathrm{O}_{-} \mathrm{O}\right)$ and during increasing doses of

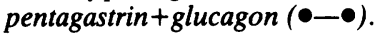

Mean plasma glucagon concentration during the combined infusion of pentagastrin and glucagon was $154 \pm 17 \mathrm{pmol} / \mathrm{l}$. Mean preinfusion blood glucose was $5 \cdot 1 \pm 0 \cdot 3 \mathrm{mmol} / 1$ and rose during glucagon infusion to $6.3 \pm 0.5 \mathrm{mmol} / \mathrm{l}(\mathrm{p}<0.05)$.

\section{Discussion}

The present study shows that intravenous infusion of glucagon in a dose resulting in plasma concentrations comparable with postprandial levels previously reported ${ }^{11}$ reduces the effect of low doses of pentagastrin on pepsin secretion, whereas the effect of a high dose $(20 \mathrm{nmol} / \mathrm{kg} / \mathrm{h} ; 10 \mu \mathrm{g} / \mathrm{kg} / \mathrm{h})$ is unchanged. Analysis of the data according to Michaelis-Menten kinetics is not possible but from the dose response curve $D_{50}$ for pentagastrin was found to be less than $0.1 \mathrm{nmol} / \mathrm{kg} / \mathrm{h}(0.05 \mu \mathrm{g} / \mathrm{kg} / \mathrm{h})$. During infusion of glucagon the $D_{50}$ was considerably higher, but it is not possible from the data to give any exact value. The observations indicate,

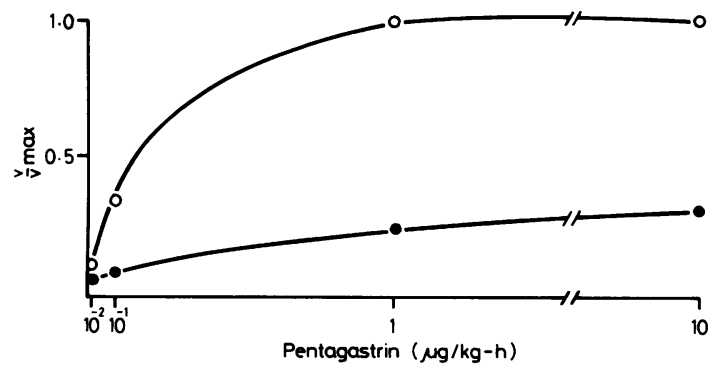

Fig. 2 Gastric acid output relative to maximum output $\left(V / V_{\max }\right)$ during intravenous administration of increasing doses of pentagastrin $(\mathrm{O}-\mathrm{O})$ and during increasing doses of pentagastrin+glucagon $(\bullet-\bullet)$. however, that glucagon markedly reduces the potency of pentagastrin for pepsin secretion.

The $D_{50}$ of pentagastrin for acid secretion was found to $0.3 \mathrm{nmol} / \mathrm{kg} / \mathrm{h}(0.15 \mu \mathrm{g} / \mathrm{kg} / \mathrm{h})$, which is of the same order of magnitude as found in a previous study $;^{2}$ this means that the sensitivity of the chief cells to pentagastrin is more than three times that of the parietal cells.

These findings contrast with studies by others, who found the same $D_{50}$ of pentagastrin for both acid and pepsin secretion in healthy subjects as well as in duodenal ulcer patients. ${ }^{12}{ }^{13}$ In the latter study, where pentagastrin was given in doses of $0 \cdot 3,3 \cdot 0$, and $30 \mathrm{nmol} / \mathrm{kg} / \mathrm{h}(0 \cdot 15,1.5$, and $15 \mu \mathrm{g} / \mathrm{kg} / \mathrm{h})$, no difference in mean pepsin output was found; this is probably due to the fact that, even with the lowest dose of pentagastrin, pepsin secretion was maximal. Pentagastrin in a dose of $30 \mathrm{nmol} / \mathrm{kg} / \mathrm{h}(15 \mu \mathrm{g} / \mathrm{kg} / \mathrm{h})$ resulted in a dose reversal of mean pepsin output. ${ }^{12}$ Thodleifsson and Wormsley ${ }^{14}$ found maximal pepsin output after a pentagastrin dose of $2 \mathrm{nmol} / \mathrm{kg} / \mathrm{h}(1$ $\mu \mathrm{g} / \mathrm{kg} / \mathrm{h})$ and dose reversal after $8 \mathrm{nmol} / \mathrm{kg} / \mathrm{h}(4$ $\mu \mathrm{g} / \mathrm{kg} / \mathrm{h}$ ), whereas in another study maximum pepsin output was obtained with pentagastrin doses ranging from $0.06-3 \mathrm{nmol} / \mathrm{kg} / \mathrm{h}(0 \cdot 03-1.5 \mu \mathrm{g} / \mathrm{kg} / \mathrm{h}) .^{15}$

The present study, combined with evidence from other studies, suggests that examination of pepsin secretion during stimulation with pentagastrin in doses used for maximal acid stimulation may be quite unreliable, as they have been performed in the dose-response range where the dose of pentagastrin is highly supramaximal for pepsin secretion, and where an unpredictable degree of dose reversal occurs.

The effect of glucagon on pentagastrin stimulated pepsin secretion consisted in a shift of the dose response curve to the right and prevention of the dose reversal after $20 \mathrm{nmol} / \mathrm{kg} / \mathrm{h}(10 \mu \mathrm{g} / \mathrm{kg} / \mathrm{h})$ of pentagastrin. How this latter observation should be interpreted is at present obscure.

Bolus injection of glucagon in pharmacological doses $(7 \mathrm{nmol} / \mathrm{kg} ; 25 \mu \mathrm{g} / \mathrm{kg})$ in man had no effect on unstimulated pepsin secretion, ${ }^{3}$ whereas histamine stimulated pepsin output was inhibited by $60 \%$ after $575 \mathrm{nmol}(2 \mathrm{mg})$ glucagon. ${ }^{4}$ If the dose-response relationship for histamine stimulated acid- and pepsin secretion is comparable with that of pentagastrin, the validity of the latter data may be doubtful.

The structure of glucagon resembles that of secretin, which, however, stimulates pepsin secretion in man, ${ }^{3}{ }^{16}$ whereas both hormones inhibit acid secretion. ${ }^{34}$ Furthermore, acid perfusion of the duodenum stimulates pepsin secretion, suggesting a physiological role for secretin or related duodenal factors as a stimulator of pepsin secretion. ${ }^{16}$ 
In conclusion, the study has shown that the potency of pentagastrin for pepsin secretion seems to be considerably higher than for acid secretion, and that glucagon reduces this potency without changing the maximal response, which contrasts with the effect on pentagastrin-stimulated acid secretion.

\section{References}

1 Christiansen J, Holst JJ, Kalaja E. Inhibition of gastric acid secretion in man by exogenous and endogenous pancreatic glucagon. Gastroenterology 1965; 70: 68892.

2 Christiansen J. Pancreatic glucagon and gastric acid secretion. Review. Scand J Gastroenterol 1980; 15: 257-8.

3 Brooks AM, Isenberg J, Grossman MI. The effect of secretin, glucagon and duodenal acidification on pepsin secretion in man. Gastroenterology 1969; 57: 159-62.

4 Cohen N, Mazure P, Dreiling DA, Janowitz HD. Effect of glucagon on histamine-stimulated gastric secretion in man. Gastroenterology 1960; 39: 48-54.

5 Dreiling DA, Janowitz HD. The effect of glucagon on gastric secretion in man. Gastroenterology 1959; 36: 580-1.

6 Hunt JW. Method for estimating peptic activity in gastric contents. Biochem J 1948; 42: 104-7.
7 Bitsch V. A modification of the Hunt method for estimating peptic activity in gastric juice. Scand J Clin Lab Invest 1966; 18: 357-8.

8 Holst JJ. Evidence that glicentin contains the entire sequence of glucagon. Biochem J 1980; 187: 337-43.

9 Widdonson GM, Penton JR. Determination of serum and plasma glucose on the 'Auto-Analyzen II' by use of the hexokinase reaction. Clin Chem 1972; 18: 299-300.

10 Riggs DS. The mathematical approach to physiological problems. Cambridge, Massachusetts: MIT Press, 1963: 270-80.

11 Rehfeld JF, Holst JJ, Kühl C. The effect of gastric on acid and amino acid-stimulated insulin and glucagon secretion in man. Eur J Clin Invest 1978; 8: 5-9.

12 Roland M, Berstad A, Liavåg I. Effect of carbacholine and urecholine on pentagastrin-stimulated gastric secretion in healthy subjects. Scand J Gastroenterol 1975; 10: 357-62.

13 Roland M. Gastric secretory response to graded doses of pentagastrin alone or in combination with carbacholine in unoperated duodenal ulcer patients. Scand $J$ Gastroenterol 1975; 10: 603-8.

14 Thodleifsson B, Wormsley KG. Aspects of the effect of metiamide on pentagastrin-stimulated and basal gastric secretion of acid and pepsin in man. Gut 1975; 16: 501-8.

15 Aadlund E, Berstad A, Semb LS. Effect of carbacholine and urecholine on pentagastrin-stimulated gastric secretion in healthy subjects. Scand J Gastroenterol 1977; 12: 501-6.

16 Brooks AM, Grossman MI. Effect of secretin and cholecystokinin on pentagastrin-stimulated gastric secretion in man. Gastroenterology 1970; 59: 114-9. 